\title{
Negative Correlation Between Economic Structure of Rentier State and Non-Democratization (Case Study: Saudi Arabia)
}

\author{
Hamid $\mathrm{S}^{1}$, Mortaza $\mathrm{B}^{2}$, Hafez $\mathrm{A}^{3} \&$ Sirous $\mathrm{S}^{2}$ \\ ${ }^{1} \mathrm{Ph}$. D of Political Science, Department of Politics and Law, Science and Research Branch Islamic Azad \\ University, Tehran, Iran \\ ${ }^{2} \mathrm{Ph}$. D Student of Political Science, Department of Politics and Law, Science and Research Branch Islamic Azad \\ University, Tehran, Iran \\ ${ }^{3}$ M.A student in international at Bonb Azad University, Iran \\ Correspondence: Hamed S, Ph. D of Political Science, Department of Politics and Law, Science and Research \\ Branch Islamic Azad University, Tehran, Iran. E-mail: hamedsarmadi2000@gmail.com
}

Received: March 14, 2018; Accepted: March 27, 2018; Published: April 8, 2018

\begin{abstract}
The Saudi Arabia having patrimonial government politically system and unique nature of power structure that all political affairs set in Ale Saudi dynasty. Government system is traditional and dependent to person and persons of dynasty are absolute rulers and away from criticism and ruler willing prefer to law. Despite of authoritarian and monarchy system and non-democracy development in Saudi Arabia special now that kind of government system isn't acceptable side of dominant discourse of global community, this country could rely on oil produce regarding to rentier state features have active representation in international communities and too in home sue achievement to legitimacy and vindication. the interests of state-building and to reinforce its legitimacy, which is hardly the act of a state free of interests. Saudi Arabia is also an archetypal example of a state that still faces influence from actors within the state and elite structures, i.e. princes, senior officials, and clerics, among others. In this article analysis rentier state effect on non-democracy development in case study of the Saudi Arabia and research claim is that in nature of relations between rentier state and non-democracy development exist negative correlation. Namely whatever government income dependent to oil export and state economic nature has been independent from peoples, will be decrease from democratic charge in political dimension. This country by oil produce and effect to world powers economies cause that be complex government structure under monarchy system and use endowment of oil rent. Now observe modern dictatorship that despite of economic and social reforms side if internal, regional and international pressures in general dimension of society, will be non-democratic politically structure.
\end{abstract}

Keywords: democracy, Saudi Arabia, rentier state, patrimonial system

\section{Introduction}

Cultural (ethnic) pluralism domination instead social (liberal) pluralism where societies not pass nation building period can be obstacle of democracy in short term. For example, Saudi Arabia is kind of traditional oligarchy, because in traditional oligarchy in political aspect we encounter lack of structural varieties and in social sphere lack of social pluralism with interference religion institutions with political institutions. In this kind of political system central government is fragile and unorganized and unapt to modernization (Nagibzadeh, 2008: 52).

By lexicology, democracy term formed combine of two Greece word comprise "Demos" meant people and "Cratia" meant rule that is geographical of govern manner (Mojtahedzadeh, 2002: 81).

On this base definition of democracy as government responsibility principal versus of people. So government formed on human equality with referendum. Deployed system when entitle as democracy that preserved civil rights and society security. Democratic manner as collective manner living that individuals having right and with equal opportunities action freely for participation in social affairs (Hashemi, 2003: 30).

Condition of political participation is political development. Political participation meant reconciliation rivalry between variety sects of society for attain to political power and definition of public expediencies. Political freedoms in society prerequisite of political participation because democracy lack of consciousness citizens participation, led convert to internal despotism and externally going to aliens dominant. Other side political and 
civil freedoms is entail communication freedoms (publication, thought and express). So political participation include series of political behaviors.

For democracy study in middle east can indicate two main index: first, apply restriction in executive branch comprise constitutions, majesty of law and balance of power system. Second, active sphere of public that including mass of people, political parties, powerful press but current reality in middle east indicate one of important democracy barricade, refer to their monarchy government model and autocratic. On this base middle east countries political systems are traditional and conservative and systems legitimacies refer to monarchy divine rights and tribal and religious roots. In this political structure, elections and political participation is slight and or not exist. Authoritarianism is major feature of Arabic states that political authority concentrated in minority group of politicians. In the other side with analysis of other democracy feature, see civil society as bed of non-governmental social common acts milieu interests, aims and common values in middle east countries are weak and fragile.

Democracy in level of a country require to exist of various institutions such as elected officials, openly elections, freedom of speech, various informing resources like that magazine, newspapers, books, mass communication instruments, efficient political parties but this process in middle east encounter challenges. Reluctance and loss of necessity sense to alternative institutions, participation express, unofficial orient of mass organizing are major causes of slump of civil society organizations in middle east. Actually citizenship concept that is entailing mutual rights and duties between peoples and sovereignty, not expanded in middle east. In spite of distinction between middle east countries politically but bans and transition to democracy is some same. Components such as lack of political infrastructures, alien powers interference, lack of bearable of active groups in social arena, some currents and ethnics authority cause that encounter democracy with serious challenges in middle east and In situation lack of democracy effect two agent in those extend. First, refer to rentier state special political economy structure. Oil dollars disposal an independent resource for Arabia governments to use for retain and reproduce of their legitimacies. On this base raise Arab state relative home independent and power from dependent of oil incomes influx of abroad. This kind of states not declination to extend of freedoms in their political system and try to satisfy people by offer services and economic activities rely to oil incomes and nor by democratic processes. Until influx oil dollars to region countries rulers, this statets responsible only public demands that necessary for retention their power and situation. So until that rent manners and styles remain, cannot consider direct bond between rentierism and responsibility principal (Nower and Martin, 2004: 13-14).

Generally, rent is incomes that a government receive from certain abroad resource with underground resources sale and aids receipt by aliens. So all of incomes that not attain by creative produce and work is entitled rent (Shekari, 2000: 31). rental income is award require by possession on natural sources that attain without effort and versus concepts like that wage and benefit. Actually any country form of rent received main portion of incomes by foreign resources is rentier stare (Mirtorabi, 2005: 113).

Seems, governments that relying to oil incomes as financial resources and having massive budget, enhance authority probability and versus governments that relying to tax and resources is little, enhance democracy probability. Robert Barrow famous economist in article entitled " determinants of democracy” present a virtual variable for states that have two-thirds of incomes by oil incomes and too taking one percent of world oil export. He explain natural resources incomes like that oil, make less pressure for democracy building than incomes rising accumulation of human and physical capital.

\section{Rentier Effect}

Researchers definition rentier effect such that a state use from abundant disposal natural resources for extenuate social pressures that otherwise rising people demands for responsibility. At least exist three supplemental effect for making this phenomenon.

1. "taxation effect" here namely in circumstances that state having adequate income by oil sale, probably recieve less tax and or take not, instead will be slake public demand possible for government responsibility and rulers representative of people.

2. "sumptury effect" that wealth can be increase government costs for patron rising and instead slake potential pressures for democratization.

3. "classical shaping effect" include when oil incomes disposal adequately financial resources, government prevent forming of independent social groups by excluding spends. This groups after forming may demand political rights. 
Oil incomes enable rentier state repel democratic and liberalists with invest in suppress tools by reducing of taxes, resources providing for patron rising, preventing forming of independent social and political groups economically (Askari, www.noormags.ir).

\subsection{Theoretic Rudiments}

Huntington ascribe cause of debility of richest oil states for "democratization" their relying to oil incomes and satiety of taxing incomes. According to rule, all of competitive regimes without taxation will not any responsibility (Huntington, 1968: 65).

Too Katoozian believe export-driven economy cause that needlessness of rulers from society and sue inadvertence to it leading to justice concept either side of rulers either people. Absence of two main elements cause creation of transmogrification movements as like revolution.

Luciani indicate to rete of economic having and political trend and ordain between its. So fix oil income cause continuity of authority and despotism and government financial crisis is main agent of demand rising and democracy exigency. Reduction of oil incomes can be anticipate democracy birth but governments not accede to people demands with reduction of oil incomes and try to retention of controlling and political blockage even less oil incomes (Alireza Soltani, Alireza Heshmatpoor, www.iaujournal.ir).

Effect of states financial resources special rental on political system structure and ruling quality in last decades had attend more itself. About consequences of state resources consider two contrary outlooks: first, rental financial resources have negative results on government political structure. Theorists of this perspective believes abundance of financial resources have negative consequences to states political and social structures (Moayedfar and colleague, 2011). Mack koor believe issue of state incomes on ruling quality is one of the important subjects in financial sociology. He proceed in numerous researches to analysis effect of state rental incomes on structure or forming of state in ruling quality in developing countries. His research results indicated state financial resources have main effects on state model structure. He expressed ruling quality will be recover in developing countries although this countries dependent to domestic financial resources economically such as taxation (Moor, 1998). In this framework more than Mack moor other thinkers indicate in numerous comparative studies that variance of state financial resources in high grade explicative of dissident in ruling quality and state efficiency and their relation with citizens (Hobson, 1997 \& Campbell, 1993).

Lam and Wantchekon (1998 \& 2000) on base of empirical data indicate that with increasing of natural sources portion in case study of exporting countries such as oil, reduction possible multiplicity of democracy in this countries and because of rules weakness is minimum participation of citizens in decision-making (Wantchekon \& Lam, 1999). Michel Rice in 2001 and Leonardo Wantchekon in 2004 with concentration on rentier states features and functions try to attain to general analysis between oil incomes and open political atmosphere in export-driven countries from intra case studies (Rice, 2001).

Freeman and colleague (2008) argued that first rule in political structure based on oil exporting and crude materials is that democracy process way in contrary to increasing of exporting of crude materials. Importance of freeman theories is for that clarifying participation crisis, administrative inefficiency, and lack of political legitimacy in rental governments. He indicated rental incomes applying with intense solution of social and economic moribund, leading to inefficiency, lack of legitimacy and extend of legitimacy crisis (Freeman \& Qunnin, 2008) (Kabiri. Jes.ui.ac.ir).

\subsection{Rentier State and Features}

Rent as economical term are incomes gain without any scholarly and manufacturing endeavor because economists became distinction between non-generative income sources - natural resources- that is more of third world incomes and with generative, exporting and taxing incomes. So rental incomes not paying for domestic economical produce activity. For example oil, gas, uranium, iron and e.tc incomes (Azghandi, 2006: 39).

According to Luciani and Beblawi definition, rental state have bellow features:

Any state gaining 42 percent or more of annual income from exporting of one or many crude material is rental state. According to rent have foreign source and not at all haven't relevant with domestic produce processes. Rental state not only having rent receive exclusive but also have authority of spending and so become to an institution of natural resources incomes distributor and or one of the main employer and investor institution (Beblawi,1975: 50). Luciani believe country that dependent to sale of ground resources as oil, it possible experiment factionalism and power struggle but away accede demand and willing in support of democracy (Luciani,1995: 426).

Beblawi counting below conditions for rentier state: 
1. Rent should be supply from abroad and haven't any relevant to production processes in domestic country economy.

2. In a rentier state engage few percent of manpower in rent production and so majority of people in society are rent receiver and distributor.

3. Rentier state also is main receiver of foreign rent and too spend it (Nasiri, 2001: 183). Seem there are a profound relative between rental states and them non-democratic nature. In this case some theorists believe although may there aren't direct relative between democracy and taxation but this is a reality that when states basically dependent to tax incomes, democracy willing will be inevitable. So such as rentier states can be responsible to society demands without dependent on internal resources, not seem democracy be a main matter and problem for them (Shekari, $2000: 23$ ).

\section{Rentierism}

Rentierism is behavior of rentier state manner. This special manner have two main features. First, rent is under control of ruler elites and second, ruler elites applying this rents for cooperate and society controlling to retain state in auspices of political stability (Haji yousofi, p:153).

Most important manner of government applying for entice of variety groups and classes are: credits grant and special loans to groups of society, increasing of government costs in internal economy, parties formation and e.tc (Shekari, 2000: 39). Rentierism lead in attenuate of developmental social groups and instead provoke nondevelopmental social groups such as state protections groups that received most advantages and interests from rent, mass of civil populate that have interests from governmental cost increase on internal economy and rural populate that have least receive rate from rents (Katoozian, 1995: 95).

Rent affections and sequences on government structure are:

1. Enhancement of state independent from society: the nature of rentier state is as that society isn't reliable because state in auspices of rent receive from abroad (oil or other any crude material) not necessity to other internal resources incomes (taxation, tolls, industrial wares exporting).

2. State needlessness of democracy making and impede in political development route in circumstances that state concentrate main power resources in hand and actually social groups haven't necessary potential for challenge creation versus state, disrupt social supervision mechanism from society and responsibility from state (Mirtorabi, 2005: 117).

\subsection{Rentier States Institutional Weaknesses in Aiding to Development}

Some researchers of development issues has been followed answering this question that why oil-bearing countries despite access to huge capitals due oil exporting, disappointed in achievement to growth and sustainable development. In oil-bearing countries such as success eastasian countries, state perform vital role in delineates and execute of development program, although formation conditions and rising of its institutional capabilities in development has basically different with developmental states because of oil incomes influx. Effective probably mechanism of oil incomes on institutional capabilities of oil exporting countries about development are:

1. Weakness in making of efficient bureaucracies

- Oil incomes and extend-over bureaucracies system

- Oil incomes fluctuate and instability of decision-making system

- Transcend of bureaucracies system distribution function, increase of corruption and deviation heightening in policy-making

2. Weakness of rentier state coalition-making capability in development route

- Weakness of rentier state connection with variety social groups

- Oil rent seeking and attenuate of state bureaucracies impartiality and coherence (ipes.razi..ac.ir/article_183_0.html).

\section{Saudi Arabia}

Race and ethnic compound of population in Saudi Arabia is 75 percent Arab, 15-20 percent Turk, Assyrian, Armenia, Turkmen, Iranian (Asadi, 2009: 235). Exist of different tribes with religion like that Wahhabis, Hanbalite, Maliki, Shafiite, Hanafite, Imami Shiite, Ismaili and Jafarite moreover of regional affiliation such as Najdi, Hijazi, tribe affiliation have imaginary subject national identity in Saudi Arabia. Model of nation in Saudi Arabia had formation base of Arab ethnical majority (from two races of Semitic and Hemitic), Arabic language (other 
languages: English, Ordu, indian, Persian) and muslim religious majority (sunnite, Wahhabis) and itself special culture (Elahi, 2009: 143).

State in Saudi Arabia not formed by colonial states but is reflex variety of geographical district that growth it. According to this reason even nationalism and capitalism cannot realize intends transforms. Saudis dynasty stressed special kind of political organization in Saudi Arabia. in this country ruled coalition of tribal chief and religious leaders that is tribal chief authority surpass of itself tribal requirements for legitimate cooperation with major religious leaders. By special quality of formation not participate all of social groups in political system or strictly unequal. Predominant feature on Saudi Arabia regarding to necessity of those nature is idea of politics based on limited connection. Political activity exist but determined its quality and range by ruler elites are Saudi dynasty family. So definition of legitimacy should be formation by this realities (Dehshyar, 2006: 22).

\subsection{Structural Obstacles of Progress and Development in Saudi Arabia}

This components are:

1. Social situation (immigrant, separated tribes, tribe affiliation and e.tc)

2. Lack of infrastructural facilities (electricity, water, road, school and hospital)

3. Lack of adequate communications between Arabia peninsular countries and transition underdevelopment

4. Lack of bartering system or very limited between regional countries

5. Lack of supplement of regional products (in industrial or agricultural) reason that has been lead those exporting and importing to out of region

6. Tribal sovereignty and political dependents

In side of this problems, Saudi Arabia encounter to other numerous problems in development route

1. Market districts due underpopulation

2. Decline of simple, skillful and expert workers

3. Lack of achievement to technical knowledge

4. Special geographical situation (water scarcity, hot and wet climate) that cause be diminish of choice right

5. Dependent to importing (including consumption, capital goods and nutraceuticals) that vulnerable them.

Saudi Arabia development strategy determined regarding to sum of internal and external agents and too regarding to limited market, limited labour, less of achievement to specialty and technical knowledge and geographical situation (Elahi, 1989: 114-115).

\subsection{Saudi Arabia Governmental Structure and Formation of Rentieral State}

Saudi dynasty family as Saudi Arabia establishment, sovereignty to all of political and economical pillars. According to Saudi Arabia constitutional, king is supreme of political position and com to power among AbdolAziz progeny. Government cabinet members elect and appoint by king and merely responsible versus him and this officials usually are among Saudi major personalities. Too consultant assembly appointed by government and provinces rulers are between Saudi princes. Sovereignty in Saudi Arabia from 1923 has been in control of the Saudi dynasty and Arabia society and social groups had haven't any role in political structure. In this country parties haven't activity right and citizens not only haven't participation right in political arenas but also some of groups and citizens such as womens, Shiites has been deprive of themselves social main rights and ever discriminate by government (Amini, 229: 164).

Generally main features of political system structure in Saudi Arabia are: authority and traditional oligarchic and patriarchy government, determinate of king and conservative Sheikhs assembly and Saudi dynasty, judicial system dependent, strict district to institutions and civil activists and new middle class, partiality-follower corrupted relations between government and tribes chiefs, traditional clericals and businessman, governmental key posts concession for Saudi princess in provinces capital, Saudi dynasty economic corruption, Saudi dynasty embezzles to increaser oil incomes, governmental suppress, sever security-informational leverage in across of country and e.tc (Sardarnia, 2010: 90). Too, the nature of Saudi Arabia is rentier and with having oil incomes and needlessness to taxation from middle class, not responsible versus them. Because of financially independent from middle class. In this wise coalition impossible between independent capital class and new middle class and sequence continue authority and irresponsibility. Oil rent cause government irresponsibility such as lead government in independent position from society and political pressures (Azghandi, 2006: 40-41). 
Arabia countries side of Persian gulf have authoritarian and closet regimes and concentrated all of power instruments (political, economical, military, judicial,legally) in hand of rules including president, Emir, Sheikh and king (Mohammadi, 1992: 78).

Political structure in Saudi Arabia, Kuwait and some of little countries side of Persian gulf is patriarchal dictatorship. Primarily this states take their legitimacies based on religious and traditional rule but in oil industry modernization process their legitimacy has been dependent to profit of oil wealth for rising life standards. Regnant often consulting to his family members about adopt of main decisions and despite of treasury department and budgeting and programming organizations, depositing incomes of resources ( special oil income) to ruler personal account. In major of Arab countries power pyramid and advantages classified alike. This pyramid is top to bottom with below sequence:

- Rule person (king, sultan, Emir, sheikh)

- Main rule dynasty members (ministers, commands and e.tc)

- Other ministers and high grade officials

- Citizens and nationals of countries ( commercials, governmental inferior cadres and e.tc)

- Immigrants including Arab, non-Arab (Emami, 2006: 80, 121).

In this countries are Emirs (Kuwait, Bahrain, Qatar), Sheikhs (septet chiefs of the united Emirate Arabia), king (Saudi Arabia) and sultan (Oman). They are symbol of an Arabic country and chief of a tribe that have leading to other tribes with itself local and traditional clothes.

In political history of edge of Persian gulf Arab countries, there aren't charismatic personality in context of weber applying but always has been powerful groups and power elites ruling to people by bigot force and family, tribal, kinsman correlatives and special foreign communications and use sum of suppress and pressure tools on people and society (Lyssee, 1995: 16). One of the major features of this societies that regarded by orientalists is patriarchal and tribal culture on people of this lands. Tribal life tradition and adopt of Sheikhs principal and charismatic tendencies that mid to magisterial is people of middle east subjective background. Leaders of major of this countries having superior power than constitutional and haven't responsibility versus of powers and tasks vis-àvis people and deputies (JavedaniMogaddam, 2006: 6).

Modernity that coincide including rational and revolution, deviated in Arabic and Islamic countries and merely reproduced and resurrect formally traditional patriarchy authority discourses and accordingly isn't actual modern person and institution. Actually social changes done superficially and undone deeply, basically and structural reforms in variety fields (Sharabi, 2006: 10).

\subsection{International System and Democracy in Saudi Arabia}

Middle east region that experimented numerous coups, riots and revolutions in last seven decades, covering conditions alike of other region countries that encounter to quintuple crises including identity, legitimacy, participation, distribution and penetration and yet have top of systemic stability rate. From 1932 as formed Saudi Arabia state whatever distinguish this country is continuity of Saudi dynasty authority. Importance of governmental stability retention as regarded that United states policy in middle east based on democratization and liberal model at a last decade in region. Saudi Arabia except of geographical importance by holy Islamic places for muslims, geopolitically and geo-strategically is biggest of Arabia country in Persian gulf region and too is greatest oil producer in global level and provider of oil importing in rete of 50 percent daily needs of the United states of America. While this strategical relations extend every day with liberal capitalism polar that now Saudi Arabia is one of the numerable societies with having sever socio-political close monarchy system in the world. Integration of Saudi Arabia with world economy and strategic system possibly by its role as a main oil producer. This country have flexibility of oil product case and can rising immediately its product near of two million barrels at day. Oil formed base of United states and Saudi Arabia relations. Saudies having a few independent in choose of foreign and economical policies. The background of Saudi Arabia indicate complex image. Main role in formation of OPEC organization in 1960, United states oil sanction in 1973-74, control of Aramco in 1970 decade and reject of Camp David treaty in last of 1970 decade. Saudi Arabia leaders retain their independent remarkably with United states. So the Saudi Arabia integration with world economy and strategic system realize with asymmetric reciprocal relations. Oil change Saudies to a strategic capital for USA and aid to monarchy security warrantee against external threats. Special features of oil increase of the Saudi Arabia pressure exert potential in internal and international levels and this country could applying this leverage for furthering of foreign policy aims (Hineh bush and Ehteshami, 2011: 353-354). 


\section{Conclusion}

Rentier state regarding to features as natural endowment for political sovereignty for spend of rule political structure prefers and its intents at society. In third world countries that have more distant with democracy development by authoritarian political structure and interests is based on rule system retention and national interests is at inferior preference, rentier sources feasible to government without rely to domestic products and taxation on citizens manage state. This act lead to diminish of citizens pressures for democracy demand. In the early years of the Kingdom, the royal elite had a symbiotic financial relationship with merchants, relying on them to provide money and goods in exchange for broader freedoms and new opportunities in their business activities as well as other concessions or privileges. Saudi Arabia was, it can be argued, rentier long before oil wealth began flowing, given the reliance of the ruling family on rents from trade and pilgrimage, and the fact that such income allowed rulers to impose far less taxation on the population than otherwise would have been the case. Saudi Arabia is a rentier state (oil exporting driven) and have patriarchal political system that providing near of 50 percent of United states needs. More than is flexibility about oil exporting and could rise oil product rate of two million barrels in day and has been direct effect in world economy. This trait is distinguish of Saudi Arabia with other rentier state and caused world powers supporting of monarchy system in this government for geoeconomical preferences and selves economical interests and ignore political underdevelopment and democracy violate. Saudi Arabia by rental incomes presence in international organizations and with financial contributions reserve their supports for retain of its political structure. In the other side rent resources is so much more that government can provide financial and economical citizens needs and too contenting tribe chiefs, other citizens and other society classes by rent distribution between governmental elements and consequently controlling democratization process in society. So could be claim that Saudi Arabia having free political economy and against close society.

\section{References}

\section{Books:}

Amini, K. (2009). Effect of nation-state building process on political stability and Saudi Arabia foreign policy, defense policies quarterlies, number of 68 .

Azghandi, A. (2006). introduction on political sociology in Iran, Tehran: Ghomes press.

Barteran, B. (2008). Political development, translated by Ahmad naghibzadeh, fifth edition, Ghomes press.

Dehshyar, H. (2006). Triangular of government retention in Saudi Arabia; United states of America, religion and oil, middle east studies quarterlies, number of 4.

Elahi, H. (1989). The Persian gulf (and its problems), Tehran: Gomes press.

Elahi, H. (2009). The Persian gulf (and its problems), Tehran: third edition, Ghomes press.

Haji, Y. A. (1998). Rentier state: a contceptual analysis, politico-economical information, number of 125-126.

Haji, Y. A. (1998). State or society relative independent in Islamic republic of Iran, strategic studies, number of 2.

Hanna, B. (1978). The Old Social Classes and the Revolutionary Movements of Iraq: A Study of Iraq's Old Landed and Commercial Classes and of its Communists, Ba'thists, and Free Officers (Princeton: Princeton University Press, 1978).

Hineau, B. R., \& Ehteshami, A. (2011). Foreign policy of middle east countries, translated by Rahman and massah ghahramanpoor, Tehran: Imam sadeq university press.

Huntington, S. (1991). political order in changing societies, translated by Mohsen salasi, Tehran: science press.

Javdanimaghaddam, M. (2006). National trust newspaper, number of 88, page of 6 .

Katouzian, H. (1995). Political economy of oil exporter countries, translated by Alireza tayyeb, politicoeconomical information, number of 95-96.

Lee, N., \& Martin, J. (2004). New face of security in middle east, translated by ghadir nasiri, Tehran: strategic study think tank.

Lysee, R. (1995). Sultans territory, translated by firouzeh khalatbari, Tehran: first volume.

Madawi, A. R. (2010). A History of Saudi Arabia, (Cambridge: Cambridge University Press, 2010).

Mirtorabi, S. (2005). Iran oil issues, Tehran: Ghomes press.

Mohammad, E. A. (2006). Internal effective agents in middle east, Tehran: international and political studies bureau. 
Mohammadi, Y. (1992). Analysis of integration dimension in Persian gulf region, Sabbah press, number of 2.

Nasiri, G. (2001), Oil and national security of Islamic republic of Iran, Tehran: strategic study think tank.

Rodney, W. (2006). Saudi Arabia's role in the global economy, in Globalization and the (Persian) Gulf, (London: Routledge, 2006).

Sardernia, Khalil-ollah (2010). New middle class and Saudi Arabia political challenges, middle east studies quarterlies, number of 3 .

Sharabi, H. (2006). New patriarchy, translated by Ahmad movasseghi, Tehran, kavir press.

Shekari, A. (2000). Rentier state theories and Iran Islamic revolution, Tehran: Islamic revolution document center.

\section{Website}

Oil incomes management structure in Norway and transition from rentier state. Retrieved from http://www.iaujournals.ir/article-525719-0.html

Comparative-phase analysis of state financial resources relation and ruler quality (interstate study. Writer: Afshar kabiri. http://jas.ui.ac.ir/article-21014.html

http://yousefi-mr.blogfa.com/post/99

http://www.aftabir.com/articles/view/economy

Effect of oil incomes on rentier state and democracy making. Writer: Mohsen askari. Retrieved from http://www.noormags.ir/view/fa/articlepage/1060840

http://ipes.razi..ac.ir/article_183_0.html

\section{Copyrights}

Copyright for this article is retained by the author(s), with first publication rights granted to the journal.

This is an open-access article distributed under the terms and conditions of the Creative Commons Attribution license (http://creativecommons.org/licenses/by/4.0/). 